\title{
Lazer Çeşitleri ve yüksek yoğunluklu lazer kullanımı
}

\section{Laser Types and using of High Intensity Laser}

\author{
İsmail Boyraz ${ }^{1}$, Ahmet Yıldız ${ }^{2}$
}

1 Tıp Fakültesi, Fizik Tedavi ve Rehabilitasyon Abd, Abant izzet Baysal Üniversitesi, Bolu. 2 Fizik Tedavi ve Rehabilitasyon, Yoncalı Hidroterapi Ve Fizik Tedavi Hastanesi, Kütahya

\section{öz}

Lazer kelimesi "Light amplification by Stimulated Emission of Radiation" kelimelerinin baş harflerinden oluşmuştur. Uyarılmış ışınım yayınımı ile ışığın yoğunlaştırılması anlamına gelen bu terim kısaca yoğunlaştırılmış ışık anlamına gelir. Lazerler enerji yoğunluklarına göre yüksek ve düşük güçlü lazerler olarak sınıflandırılır. Lazerin etki mekanizmaları tam olarak tanımlanmamış olmasına rağmen subsellüler ve sellüler mekanizlamarı etkilediği gösterilmiştir. Lazerin temel etki mekanizması doku stimülasyonudur. Bu uyarı hücre, vasküler yapı, interstisyel doku ve immün sistem seviyelerindedir. Lazerin analjezik ve antiinflamatuvar etkinliği birçok mekanizma ile ile açıklanmaktadır. Duysal sinir uçlarında ağrı algılanması ile kas arteriyollerindeki spazmı azaltarak reaktif vazodilatasyon oluşturur. Yüksek yoğunluklu lazer başlangıçta doku ablasyonu ve cerrahi girişimlerde kullanıldı. Fizyoterapide kullanımı son yıllarda artmıştır. Yüksek yoğunluklu lazer antiinflamatuvar, antiödemik ve analjezik etkileri sayesinde iyileşme sağlamaktadır. Son çalışmalarda dokuların rejeneratif sürecinde, kemik formasyonunun oluşmasında, yeni kıkırdak sentezinde ve kartilaj matriks sentezinde etkili olduğu saptanmıştır.

Anahtar Kelimeler: Lazer, Fizik Tedavi Modaliteleri, Ağrı Tedavisi

\section{ABSTRACT}

The word laser is composed of the first letters of the words "Light Amplification by Stimulated Emission of Radiation". This term meaning the intensification of light by propagationof stimulated radiation means briefly intensified light. Lasers are classified as higher energy density and lower power lasers. Although the mechanisms of laser precisely defined, subcellular and cellular mechanisms have been affected. Basic mechanism of laser is tissue stimulation. This effects are on the cells, vascular structures, interstitial tissue and the immune system levels. The analgesic and anti-inflammatory activity of the laser is described by several mechanisms. Reducing muscle spasms in arterioles with the perception of pain in the sensory nerve endings creates reactive vasodilation. High intensity was initially used in tissue ablation and laser surgery. Using of the laser at physiotherapy has increased in recent years..High-intensity laser provides healing through anti-inflammatory, antiedeme and analgesic effects. Upon tissue regenerative processes, the formation of bone formation, the synthesis of new cartilage in recent studies and at the same time in cartilage matrix synthesis have been found to be effective.

Keywords: Laser, Physical Therapy Modalities, Pain Management

Corresponding Author: İsmail Boyraz

Address: Tıp Fakültesi, Fizik Tedavi ve Rehabilitasyon Abd,

Abant İzet Baysal Üniversitesi, Bolu-Turkey

Başvuru Tarihi/Received:

Kabul Tarihi/Accepted:
16-06-2016

10-07-2016

E-mail: boyraz@yahoo.com 


\section{GiRiş}

Lazer kelimesi "Light amplification by Stimulated Emission of Radiation" kelimelerinin baş harflerinden oluşmuştur. Uyarılmış ışınım yayınımı ile ışığın yoğunlaştırılması anlamına gelen bu terim kısaca yoğunlaştırılmış ışık anlamına gelir. Lazerin prensipleri 1927 yılında Einstein tarafından ortaya konulan kuantum kavramına dayanmaktadır. 1954 yılında Townes ve arkadaşları Colombia Üniversitesinde bu kavramı Maser ( Microwave Aplification by Stimulated Emission of Radiation) şeklinde uygulamaya başlamışlardır. 1960 yılında Teodore Maiman ilk laser aletini geliştirmiştir. 1967 yılında lazer ile ilgili ilk deneysel çalışmalar başlamış ve lazerin biyostimülan etkisi anlaşılmıştır. 1968 yııında Mester düşük enerjili lazerin hücreler üzerinde uyarıcı etkili, yüksek enerjili lazerin ise inhibitör etkili olduğunu ortaya çıkarmıştır (1).

Lazer cihazlarının temel prensibi bir ışık kaynağından çıkan foton enerjisinin belirli bir ortamdan geçirilmesi yoluyla, bu ortamın atomlarındaki elektronların dönüş hızını artırmak ve böylece gelen ışınlardan çok farklı dalga boyunda, tek bir doğrultada hareket eden yeni bir ışın elde etmektir (2).

Lazer ışınlarını elde etmek için radyasyon emisyonu sağlayacak aktif bir ortam (katı, sıvı, gaz), enerji kaynağı, elektron hareketlerini hızlandırmak için rezonans ayna sistemi ve fiber-optik bir iletken gereklidir (3). Einstein' e göre atomlar ve moleküller sürekli bir osilasyon durumunda bulunurlar. Bu osilasyon sırasında enerji yönünden uyarılmış durumdadırlar. Uyarılmış atomların bazıları 810 sn gibi çok kısa için sabit duruma geçerler ve bu esnada bir foton enerjisi ortaya çıkar. Meydana gelen bu foton enerjisi lazer ortamının iki ucuna konulan rezonans aynalar arasında gidip gelmesi sağlanarak amplifiye edilir. Bu aynalardan biri yarı geçirgen olduğu takdirde meydana gelen enerji buradan çıkıp yeni bir ışık şeklinde boşlukta yol alacaktır. Meydana gelen bu ışık fiziksel özellikleri farklı olan lazer ışığıdır (3).

\section{Lazer Işığının Fiziksel Özellikleri:}

Elektromanyetik spektrumda görünür ışık ve kırmızı ötesi bölgesinde yer alan lazerin fiziksel özellikleri şunlardır:

Monokromatizm (tek renklilik, fotonların birbirleriyle uygunluğu). Lazer ışınları tek bir dalga boyundaki ışınlardan oluştuğu için tek renklidir. Bu özellikten dolayı bazı dokular ve ve spesifik uygulamalar için belli dalga boylarının seçilmesine olanak sağlar. Örneğin Helium- Neon cihazı dalga boyu $632.8 \mathrm{~nm}$ olan kırmızı lazer ışını, Galium- Arsenid cihazı dalga boyu $910 \mathrm{~nm}$ olan kızıl ötesi lazer ışınıdır (1).

Koherans (uyumluluk, dağılmazlık): Güneş ışını veya elektrik ampülü gibi kaynaklardan çıkan ışık dağınık bir şekilde etrafa yayılır. Işığı oluşturan dalgalar aynı anda aynı fazda bulunmadığı için bu şekilde yayılmaktadırlar. Normal ışığın tersine lazer ışını dağılmaz, aynı yön ve aynı fazı ortalayan paralel dalgalardan oluşur. Lazer dalgalarının düzenliliğinin nedeni uyarılmış yayınımdır. Normal ışık kaynaklarından yayılan ışın ise spontan yayınım sonucu oluşmaktadır. Lazerin bu özelliği ile sapma en aza indirilir ve enerjinin bir noktada toplanması sağlanır.

Küçük diverjans (Küçük oranlarda dağııırlık): Normal ışık çok kısa sürede ve mesafede yayılmaktadır. Lazer ışını ise küçük diverjans göstermesi nedeniyle saç kılı inceliğinde uzak mesafelere aynı incelikte ulaşabilmektedir. Bu nedenle lazer için doğrultulmuş ışın (kolimasyon) ifadesi kullanılmaktadır (4). 
Enerji taşıyıcılık: Lazer ışınlarının büyük bir elektromanyetik alan gücü vardır ve bu özelliklerinden dolayı enerji taşıyıcıdırlar. Küçük yüzeylere yoğun bir enerji aktarır. Radyant enerjinin diğer tiplerine benzer şekilde absorbe edilebilir, yansıtılabilir ve iletilebilirler.

Lineer polarizasyon: Optik filtreler sayesinde sadece $90^{\circ}$ ile gelen ışınların geçmesine izin verirler (3).

\section{LAZER TIPLERi:}

Lazerler enerji yoğunluklarına göre yüksek ve düşük güçlü lazerler olarak sınıflandırılır. Yüksek güçlü lazerler ürettikleri termal etki nedeniyle sıcak lazerler ismini de alırlar ve daha çok cerrahi uygulamalarda kullanılır. ABD'de düşük enerjili lazerler en çok $1 \mathrm{~mW}$ çıkışlıdırlar, bu yüzden daha çok fotokimyasal olarak etki ederler. Düşük enerjili lazer, düşük güçlü lazer, düşük seviyeli lazer, yumuşak lazer gibi isimler alırlar.

Argon lazer: Daha çok göz hastalıklarında kullanılırlar. Retinal kanamalarda, dekolman ve glokomda kullanımı sıktır.

CO2 lazer: Mikro cerrahi kullanımlar için en uygun lazer çeşididir. Dokuların üst tabakaları tarafından emildiği için temiz ve az kanamalı kesi olanağı sağlamaktadır. Ayrıca çapı 0.5 mm' ye kadar olan damarların kapatılmasını sağlar.

Neodyum YAG (Ytrium Aluminyum oxide Garnet) lazer: Özellikle tümör tedavisinde ve endoskopide kullanılır. Önce ısınma sonra yavaş yavaş ilerleyen derin pıhtılaşma ve doku yüzeyinde büzülmelere neden olur. Işınlama devam ederse buharlaşma meydana gelir.

Helyum- Neon (He-Ne) lazer: Yüksek dağılım ve düşük absorbsiyonda geniş bir doku kitlesine etki eder. Transkutan Işınlama tedavileri için en uygun lazer tipidir. Kollajen liflerin ve hücrelerin çoğalmasını sağlar. Ağrıyı azaltır.

Lazer sınıflamasında farklı bir bakış açısı olan düşük güçlü lazer (yumuşak lazer), orta güçte lazer (mid lazer) ve güçlü lazer (sert veya sıcak lazer) olmak üzere üç farklı grupta incelenebilmektedir.

Düşük güçlü lazerler: Helyum neon gazını kullanır. Transkutan ışınlamada en uygun lazer tipidir. $632.8 \mathrm{~nm}$ dalga boylu lazerdir. Emniyetli ve pratik olup, devamlı ışın yayarlar. Pulse veya devamlı uygulanma tipleri vardır. Işık kaynağına devamlı bakııırsa gözde tahribat yapmaktadır. Helyum neon lazerin penetrasyon derinliği direk olarak $0.8 \mathrm{~mm}$ ' nin üzerindedir. İndirekt olarak ise $10-15 \mathrm{~mm}$ 'yi bulmaktadır. Direkt penetrasyon lazerin karakteristik özelliğinin değişmeden ulaştı̆̆ı mesafeyi ifade eder. İndirekt penetrasyon ise lazerin özelliğinin değiştiği çevre dokuların özelliğine göre absorbsiyonun gerçekleştiği mesafeyi tanımlar (4).

Orta güçte lazerler (Mid lazerler, yarı iletken lazerler): Aktif madde olarak galyum aluminyum arsenid maddesini kullanırlar. Bazı sınıflamalar orta güçteki lazerleri düşük kategoriye alabilmektedir (1). Diyod lazer olarak ta tanımlanmaktadırlar. Pulse ışın yaymaktadırlar. İndirekt penetrasyon $5 \mathrm{~cm}$ 'ye kadar çıkmaktadır. Diyot lazerleri tam olarak kohoren yapmak zor olmaktadır. Bu nedenle daha ucuza oluşturulabilen süper ışık (superluminus) diyodlar vardır. Ancak non kohorent özelliktedirler. Tedavi amacıyla yaygın kullanılmaktadır.

Güçlü lazerler ( sert veya sıcak lazerler): Cerrrahide ve sanayide sık kullanılmaktadır. Argon, karbondioksit, neodyum YAG (yitrium aluminyum okside garnet) lazerleri vardır. Argon lazer göz hastalıklarında, karbondioksit lazer mikrocerrahide kullanılmaktadır. Neodyum YAG lazerin dalga boyu 1064 nm'dir. 
Son yıllarda yüksek yoğunluklu lazer fizik tedavi uygulamaları arasındaki yerini almıştır. $\mathrm{Bu}$ etki Nd:YAG lazerin $1064 \mathrm{~nm}$ dalga boyundaki formuna ek olarak Galyum Aluminyum Arsenid (GaAlAs) lazerin 1064 nm dalga boylu yüksek yoğunluklu formu ile de sağlanabilmektedir.

\section{Lazerin Etkileri ve Etki Mekanizmaları:}

Lazerin etki mekanizmaları tam olarak tanımlanmamış olmasına rağmen subsellüler ve sellüler mekanizlamarı etkilediği gösterilmiştir (5). Lazerin temel etki mekanizması doku stimülasyonudur. Bu uyarı hücre, vasküler yapı, interstisyel doku ve immün sistem seviyelerindedir. Lazerin biyostimülasyonundan sorumlu etkinin polarizasyon olduğu bildirilmiştir. Ayrıca lazerin dokulara uygulandığında direkt, akupunktur noktalarına uygulandığında ise sistemik etkisi vardır (6).

Lazer ışınlarının fotonları biyolojik ortama girdiklerinde kendileri ile uyumlu enerji seviyeleri olan organizma moleküllerine enerji verirler. Kırmızı ışık lazer (600-700 nm) suda absorbe olduğu için derinin altında 4-5 mm'den derine gidemez. Kırmızı ötesi lazer suda absorbe olmadığından deri altında 5-6 $\mathrm{cm}$ mesafedeki kemik eklem ve kas gibi hedef dokuya etki edebilir (1).

$\begin{array}{llr}\begin{array}{l}\text { Lazerin vücut üzerine } \\ \text { biyostimülan }\end{array} \text { etkisi hücresel } & \text { seviyede } \\ \text { mitokondriler tarafından absorbe } & \text { edilerek, } \\ \text { ATP havuzu ve sitoplazmik } & \text { hidrojen }\end{array}$
yoğunluğunun artması ile açıklanabilir. Bunun sonucunda hücre zarının iyonlara geçirgenliği artmaktadır. Yara iyileşmesinin inflamatuvar fazında lazer uyguladığımızda yara iyileşmesi medyatörlerinin, iyileşmenin geç döneminin başlaması için uyarıcı etki yaptığı ileri sürülmüştür. Ayrıca kartilajın deneysel olarak yıkıldığı hayvan çalışmalarında lazer tedavisi ile klinik ve histolojik olarak anlamlı iyileşme bildirilmiştir (7).

Laboratuvar çalışmalarında kollajen üretimini artırmakta, DNA sentezini değiştirmekte ve nörolojik doku hasarlarında fonksiyonu iyileştirmektedir. Bu etkiler insanlar üzerinde yeterli kanıt düzeyine sahip değildir (8). Lazer uygulamasının hücre kültürlerinde hücrelerin hem metabolizma hem de hücre yüzeylerindeki etkisi gösterilmiş ancak yapıda herhangi bir değişiklik yapmadığı bildirilmiştir (9).

Lazerin analjezik ve antiinflamatuvar etkinliği birçok mekanizma ile ile açıklanmaktadır. Duysal sinir uçlarında ağrı algılanması ile kas arteriyollerindeki spazmı azaltarak reaktif vazodilatasyon oluşturur. Romatoid sinoviyal membranda protein sentezi ile rejenerasyonu ve beta endorfinleri artırarak analjezik ve antiinflamatuvar etki yapar (6). Lazerin ayrıca kemik iliğinde hematopoezi uyardığı ve immün sistemi stimüle ederek antibakteriyel etki gösterdiği ileri sürülmektedir (6). Lazer doku ısısında belirgin bir değişiklik yapmaz. Bu olay lazerin potansiyel fizyolojik etkisinin ısıdan bağımsız olduğunu gösterir (1). He-Ne lazerin enerji soğurumu yüzeysel yapılarda özellikle yumuşak dokunun ilk 2-5 mm'sinde meydana gelmektedir. Bu direkt etkisidir. Indirekt etki 8$10 \mathrm{~mm}$ derinlikte oluşmaktadır.

\section{Lazerin dozu:}

Etkin bir tedavi için lazerin dozu ve tedavi süresi lazerin tipi de dikkate alınarak iyi belirlenmelidir. Lazerin etkin olmadığı çoğu çalışmada yeterli olmayan dozlarda lazerin kullanıldığı saptanmıştır (1). Doz tedavi sırasında uygulamanın direkt olarak yapıldığı alandaki enerji miktarıdır. Enerji birimi Joule (J), ışık alanı lazer ışığı çapı olarak hesaplanır. Doz $(\mathrm{J} / \mathrm{cm} 2)=$ Enerji $(\mathrm{J}) /$ ş̧ık alanı $(\mathrm{cm} 2)$ formülüyle saptanır. Lazer dozunun 
saptanmasında çeşitli parametreler mevcuttur.

Güç yoğunluğu $(\mathrm{W} / \mathrm{cm} 2)=$ Lazer Güç Verimi (W)/ Işık Alanı (cm2)

Buna benzer şekilde ışık alanı, enerji yoğunluğu, tedavi zamanı gibi parametreler hesaplanabilmektedir. Düşük doz lazer tedavisi $0.5 \mathrm{~J} / \mathrm{cm} 2$ dozunda verildiğinde hedef dokuda fotobiyolojik etki oluşturur. $4 \mathrm{~J} / \mathrm{cm} 2$ dozu yara iyileşmesinde etkilidir. Doku iyileşmesi ise $0.5 \mathrm{~J} / \mathrm{cm} 2-5 \mathrm{~J} / \mathrm{cm} 2$ aralığında olmaktadır. 8-12 J/cm2 dozu biyoinhibisyon sağlar ve keloid skarlarının tedavisinde kullanılır (3). Lazer tedavisi her gün uygulanabilir. Bir seans uygulamada $100 \mathrm{~J}$ total doz aşılmamalıdır. Tedavi süresi endikasyona göre değişkendir. Seans sayısı 10-20 arasında uygulanabilir (2,3). He-Ne lazer uygulamalarında ağrı için 16-20 sn,yaralar için 20-30 sn uygulanır. Frekansı ise doku iyileşmesinde 5-20 puls, ağrı için 20-80 puls uygulanabilir. Tedavi için cilt üzerinde düşük dirençli noktaların tespiti önemlidir.

\section{Lazer Tedavisinin Endikasyonları:}

Osteoartrit, yumuşak doku romatizmaları, romatoid artrit, yanık iyileşmesi, dekübitis ülseri, KTS, tendinit ve bursitler, peyronie hastalığı, spor yaralanmaları, radikülopati ve diskopatiler, kronik osteomyelit, diyabetik nöropati, epikondilit, diş hastalıkları, trigeminal nevralji, postherpetik nevraljiler, sjögren sendromu, kırıklarda kemik oluşumu, skar tedavilerinde kullanılabilir.

\section{Lazer}

Tedavisinin

\section{Kontrendikasyonları:}

Çocuklarda kapanmamış fontaneller üzerine, hamilelerde, kanserli lezyona yakın bölgelere, variköz venlere ve iltihabi alanlara uygulanmamalıdır. Epilepsi tanısı olanlara ve kalp pili taşıyanlarda çok dikkatli bir şekilde uygulanmalı veya da hiç uygulanmamalıdır. Bir metreden kısa mesafeden göze yöneltilen lazer kornea tarafından yoğunlaştırılıp göze zarar verir. Hasta ve doktor mutlaka gözlük takmalıdır (1).

\section{Yüksek Yoğunluklu Lazer (Hilt)}

Fototerapi hastalıkları önlemek ve tedavi etmek için çok uzun yıllardır geniş bir kullanım alanına sahiptir. Firavun zamanına dayanan ışık ve güneşle ilgili çalışmalar olduğu düşünülmektedir. Diğer kaynaklarla karşılaştırıldığında lazerin ışınının en büyük avantajı yayılan ışının tek renkliliği ve yüksek yoğunluğudur. Ayrıca optik kablolarla güçlendirilebilmesi, etkili bir şekilde fokalize edilebilmesi büyük avantaj sağlamaktadır. Lazerlerin tıpta pek çok alanda geniş uygulamaları vardır. High intensity laser therapy (HILT) olarak bilinen yüksek yoğunluklu lazer tedavisi ise 2002 yılında FDA onayı almıştır. Dünya modern tıp merkezlerinde ve hastanelerde giderek popüler olmakta ve güvenle kullanılmaktadır. Geniş bir literatür bilgisine rağmen lazerin çok çeşitleri olması, biyolojik hedef dokuların ve bu dokulardan alınan yanıtların çok farklı olması nedeniyle moleküler ve hücresel düzeyde etkinliğini anlamak zordur (10).

Etkileşim zamanına ve etkili güç yoğunluğuna dayanarak lazer ışını ve doku arasındaki etkileşim 3 tipe ayrıştırılabilir; bunlar fotokimyasal, fototermik ve fotomekanik etkilerdir (11). İlk fizyoterapide kullanılmış olan düşük yoğunluklu lazerin sebep olduğu etki fotokimyasal etkisine bağlıdır. $\mathrm{Bu}$ etkiler dokularda tanınan endojen ve ekzojen kromoforların uygun dalga boyundaki ışınları absorblaması ile gerçekleşir. Bir foton absorblayan kromofor molekülü uyarılmış duruma dönüştürülür. Bunun sonucunda biyolojik etkiye sebep olan kimyasal reaksiyona katılabilir. 
Yüksek yoğunluklu lazer başlangıçta doku ablasyonu ve cerrahi girişimlerde kullanıldı çünkü fototermal ve fotomekanik etkiler üretebilmektedir. Fizyoterapide kullanımı son yıllarda artmıştır ve bu kullanım doku hasarı yapmadan terapötik fototermal ve fotomekanik etkilerin elde edilmesi için kontrol edilebilir emisyon yaklaşımlı lazer sistemlerinin gelişmesi sayesinde mümkün olmuştur. Özellikle pulse $\mathrm{Nd}$ :YAG lazer çok çesitli kas iskelet sistemi hastalığının tedavisinde faydasını ve çok yönlü etksini ispatladı. Yüksek yoğunluklu lazer bu etkilerini antiinflamatuvar, antiödemik ve analjezik mekanizmaları sayesinde gerçekleştirmektedir (12).

Son çalışmalarda dokuların rejeneratif sürecinde, kemik formasyonunun oluşmasında, yeni kıkırdak sentezinde ve kartilaj matriks sentezinde etkili olduğu saptanmıştır $(13,14)$. $\mathrm{Nd}: Y A G$ lazerin tendon ve ligaman lezyonlarında iyileşme sürecine katkıda bulunduğu ve fibrozis gelişimin engellediği saptanmıştır (14). Diğer lazer kaynaklarıyla karşılaştırıldığında pulsed Nd:YAG lazerin doku kromoforları ve hücreler tarafından hafifçe emilen bir dalga boyuna sahip olması (1064 nm) nedeniyle dokulara yüksek penetrasyon yapabilme ve derin doku ve yapıların tedavisini sağlayabilme imkanı sunar. Üstelik fototermal etki akım yoğunluğunun ve frekansının ayarlanmasıyla güvenlik ve rahatlık açısından kontrol edilebilir. Yüksek yoğunluklu lazerin etkilerini şöyle açıklayabilir:

- Nd:YAG lazer ışını hücrelerde sitoskeleton ağının yeniden düzenlenmesi,

- Konnektif doku hücrelerinin ekstrasellüler matriks üretiminde artışa yol açarak doku tamir ve rejenerasyonuna katıkıda bulunur,

- Fibronektin üretiminin/dağıtımının düzenlemesi ve fibril düzenlenmesinin regülasyonu ile endotelyal hücre fonksiyonlarını güçlü bir şekilde etkilemektedir,
- Mezekimal kök hücrelerinde spesifik farklılaşmıs cevaplara neden olur,

- Değişmiş fenotipik ifadeyle uyumlu olarak gen ekspresyon profilinde değişiklikler yapar (10).

HILT 'in temelinde sellüler değişiklikler sonucu olan cevap yatmaktadır. Nd:YAG lazer mezenkimal kök hücreler ve endotelyal hücreler yanında konnektif doku hücrelerinde mekanik yüklenme tarafından oluşturulan etkiye yakın cevaba neden olur. Hücreler pulse Nd:YAG lazer ışınlarını mekanik stres olarak algılarlar ve mekanotrandüksiyon makineleri kanallarıyla cevap verirler.

\section{REFERANSLAR}

1. Serap Alper. Fiziksel Tıp ve Rehabilitasyon In: Mehmet Beyazova, Yeşim Gökçe Kutsal. Fiziksel Tıp ve Rehabilitasyon. Volume 1, Ankara: Güneş Tıp Kitabevi, 2011:823-826.

2. Naeser MA, Hahn KA, Lieberman BE, Branco KF. Carpal tunnel syndrome pain treated with low-level laser and microamperes transcutaneous electric nerve stimulation: A controlled study. Arch Phys Med Rehabil 2002;83(7):978-988.

3. Snyder-Mackler L, Bork CE. Effect of helium-neon laser irradiation on peripheral sensory nerve latency. Phys Ther 1988;68(2):223-225.

4. Hidayet Sarı, Kenan Akgün. Hareket sistemi hastalıklarında fiziksel tıp yöntemleri. Ankara: Nobel Tıp Kitabevi, 2002:73-79.

5. Basford JR. The clinical status of low energy laser therapy in 1989. J Laser Appl 1990;2(1):57-63.

6. Ozdemir F, Birtane M, Kokino S. The clinical efficacy of lowpower laser therapy on pain and function in cervical osteoarthritis. Clin Rheumatol 2001:20(3):181-184.

7. Bayat M, Ansari E, Gholami N, Bayat A. Effect of low-level helium-neon laser therapy on histological and ultrastructural features of immobilized rabbit articular cartilage. J Photochem Photobiol B 2007;87(2):81-87.

8. Gur A, Karakoc M, Cevik R, Nas K, Sarac AJ. Efficacy of low power laser therapy and exercise on pain and functions in chronic low back pain. Lasers Surg Med 2003;32(3):233-238.

9. Kubasova T, Kovacs L, Somosy Z, Unk P, Kokai A. Biological effect of $\mathrm{He}-\mathrm{Ne}$ laser: investigations on functional and micromorphological alterations of cell membranes, in vitro. Lasers Surgery Med 1984;4(4):381-388.

10. Monici M, Cialdai F, Fusi F, Romano G, Pratesi R. Effects of pulsed Nd YAG laser at molecular and cellular level. A study on the basis hilterapia. Energy for health 2008;26-33.

11. Jacques SL. Laser-tissue interactions. Photochemical, photothermal, and photomechanical. Surg Clin North Am 1992; 72(3):531-558.

12. Zati A FD, Valent A. High intensity laser therapy versus TENS and NSAIDs in low back pain: clinical study. SPIE Proceed 2004;5610:277278.

13. Arisu HD, Turkoz E, Bala O. Effects of Nd:Yag laser irradiation on osteoblast cell cultures. Lasers Med Sci 2006;21(3):175-180.

14. Spivak JM, Grande DA, Ben-Yishay A, Menche DS, Pitman MI. The effect of low-level Nd:YAG laser energy on adult articular cartilage in vitro. Arthroscopy 1992;8(1):36-43. 